\title{
मानवीय जीवन पद्धति र बुद्धदर्शन
}

\section{डा. जगतप्रसाद पराजुली}

\section{सारसंक्षेप}

पृथ्वीमा मानवरूपी शरीर लिएर जन्मिनु आफैमा एउटा महत्तपूर्ण घटना हो। यसलाई युगान्तकारी परिघटनाको रूपमा पनि स्वीकार्न सकिन्छ। यस संसारमा अबतरित भएर जीवनलाई सार्थक बनाउने किसिमका सबैखाले नैतिक, चारित्रिक, आध्यात्मिक लगायतका समसामयिक पक्षहरूलाई सवल र उपलब्धिमूलक बनाउन गरिएका वैध कृयाकलापहरू, खेलिएका भूमिका, पुयाएको योगदान आदिले मानवीय जीवन पद्धतिलाई प्रभावकारी तुल्याइरहेको हुन्छ। हरेक दिन, प्रत्येक प्रहर मानिसको जीवनसंग सुख, दु:ख, लाभ, हानी, निन्दा, प्रशंसा, यश ₹ अपयश गरी 5 वटा लोकधर्म सानिध्य र अन्योन्यास्रित भएर निरन्तर दोहोरिरहन्छन्। बुद्धद्वारा प्रदत्त उत्तम मंगल देशनाद्वारा तिनीहरूको परिपालन गर्न ३५ वटा मंगल धर्मको मार्ग वा उपाय अवलम्बन गर्न सुकाइएको छ। जन्मदेखि मृत्युसम्म नै सुखान्तक र दु:खान्तक परिवेशले छायाँ बनेर लगातार पच्छुयाइरहेको हुन्छ। यस्तो स्थितिलाई संयमित, अनुशासित, मर्यादित तथा अविचलित भएर सुल्काउन सद्कार्य गरिहनु आवश्यक हुन्छ। यसका लागि पनि भगवान् बुद्धले दशपारमिताको उपाय र समरूपी मध्यस्थ बिन्दुको माध्यमबाट पार पाउन सकिने उपदेश दिनुभएको छ। शोक, दु:ख र विपत्तिको शिकार हुन नदिनू यो आफैमा सर्वोत्कृष्ट मार्ग हो।

मानिसको जीवन सधैं सरसपूर्ण, सहजपूर्ण, सरलतम, फराकिलो र निस्फिकी ढंगले मात्र अगाडि बढ़दैन, सरल रेखाबाट मात्र परिचालित हुँदैन। अनेकौँ विह्नवाधा, हन्डर, भुक्तमान र विशमयका जंघारहरू पनि तर्नुपर्छ, सहन गर्नुपई । यसका लागि सन्तुलित, सुरक्षित, शितल र निर्भयताका साथ उभिनु अनिवार्य हुन्छ। यसर्थ जीवनलाई समभाव, समदृष्टि र समव्यवहारबाट सुसज्जित गराउनु अपरिहार्य छ। शान्ति, अमनचयन, सुख, समृद्धि आदि बाहय सतहमा हुँदैन। त्यसैगरी विश्मयादी परिदृश्य पनि बाहिरको क्षितिजमा निहित रहंदैन। ती सबै क्षणहरू आफूभित्र नै अन्तरनिहित हुन्छन्। गुलाफको फूलको जीवनवृत्त जस्तै मानवरूपी शरीरभित्र नै तिनीहरूको अस्तित्व रहन्छ। फेरबदल, चलखेल र विकासकम पनि दुबै पाटाबाट अविच्छिन्न रूपमा परिचालित भइरहन्छ। मानव जीवनलाई सुसंगठित, सुव्यवस्थित, सुनियोजित र सुनिश्चित तुल्याउन, बुद्धदर्शन नै अद्वितीय अनुपम, अतुलनीय र औपदेशिक शिक्षाद्वारा सम्भव हुन्छ। बुद्धर्मसंग सम्बन्धित अलौकिक, लौकिक, परलौकिक, आध्यात्मिक विधाहरूलाई हृदयड्गगम गर्नु, अनुशरण गर्नु र अनुकरण गर्नु श्रेयस्कर ठहछ।

शब्दकुज्जी : युगान्तकारी परिघटना, लोकधर्म, उत्तम-मंगल, दशपारमिता र अतुलनीय उपदेश ।

* डा. पराजुली, सहप्राध्यापक, विभागीय प्रमुख, इतिहास तथा बौद्ध अध्ययन विभाग, पाटन संयुक्त क्याम्पस, पाटनढोका । फोन न. ९५ २२३३३७३, Email: jagatparajuli792015@gmail.com/ parajuli310@gmail.com 


\section{अध्ययन विधि}

बुद्ध धर्मसँग सम्बन्धित बहुआयामिक महत्त्वका ग्रन्थहरू अनगिन्ति छन् । ती ग्रन्थहरूलाई आध्यात्मिक, धार्मिक, दार्शनिक पक्षबाट सिंहावलोकन गरिएका छन् । कतिपय ग्रन्थहरूले साहित्यिक विधाका अनेकौँ फाँटहरूबाट लगातार रसस्वादन गराउन सक्षम भएका छन्। व्यवहारिक जीवनसंग अनिवार्य र अपरिहार्य हुने गरी अनेकौ आयामहरूमा तिनीहरूले मार्गनिर्देशन गरिरहेका छन् (लि., २००६ : ९, ३५, १०६, १३०)। बुद्धधर्ममा अन्तरनिहित अनुपम शैक्षणिक पक्षहरूले मानवीय जीवनलाई बहुप्रतिभाशाली कल्याणकारी र वृहत्तर प्रभावशाली तुल्याउन पथप्रदर्शन गरिरहेका छन्। दार्शनिक, विद्वान, विदुषीहरूले बहुपक्षीय र बहुकोणीय दृष्टिबाट कृतिहरू संरचना गरिनैरहेका छन् । लेखक-लेखिकाहरूले बुद्धदर्शनलाई मानवोपयोगी हुनसक्ने किसिमले समसामयिक र समयसापेक्षित बनाउँदै व्यवहारिक जीवनलाई सुसंस्कारयुक्त, सुसंस्कृतियोग्य र सुसभ्य तुल्याउन निरन्तर प्रयत्नशील भइरहेका छन् (सान्तिना, १९९७ : १०९, ३०१, ३३५)। विश्वव्यापीरूपमा देखिएका अशोभनीय संकट र अमानवीय कृयाकलाप-हरूलाई निस्तेज गर्न, निराकरण गर्न, न्युनीकरण गराउन र समूल रूपमा निवारण गर्न आफूसँग भएका ऊर्जा, सीप र प्रतिभाहरू प्रदर्शन गरिरहेका छन् । विश्वबन्धुत्व र भाइचारामा प्रतिबद्ध हुँदै "बसुधैव कुटुम्बकम्" को आदर्शलाई वृहत्तर रुपमा विस्तार गर्न भरमगदुर प्रयास गरिरहेका छन्। "सर्वजन हिताय सर्वजन सुखाय"को अवधारणालाई विश्वव्यापीकरण गर्न अथक मेहनत पनि गरिरहेका छन्।

प्रस्तुत रचनाको विषय, शीर्षक, परिधि, स्वरूप, प्रकृति, क्षेत्र र महत्त्व निकै व्यापक छ। विस्तृत र वृहत्तर स्वरूपको विषयलाई सम्पूर्ण रूपमा छिचोल्न मुश्किल पई। प्रशस्त कृतिहरू प्रकाशित भएको कारण सर्व पुस्तक एवम् कृतिहरूको साङ्गोपाड्गो अध्ययन, अनुशीलन र विश्लेषण गर्न पनि कठिन हुन्छ, (अमृतानन्द, २०४५ : ९, २१, ७४, ११७) । अतः सुलभ भएका पुस्तकहरूलाई सहायक स्रोत तथा सामग्रीको रूपमा ग्रहण गरी तिनीहरूबाट प्राप्त सूचनाहरूलाई समुचित उपयोग गर्दे विभिन्न विद्वान्-विदुषीहरूको प्रवचन, साक्षात्कार, मन्तव्य तथा भनाइहरूलाई प्राथमिक स्रोतको रूपमा परिशोधन पश्चात् ग्रहण गरिएको छ। केही सरोकारवाला सूचनादाताहरूबाट अन्तर्वार्ताको माध्यमबाट मौलिक सूचनाहरू प्राप्त गरी सत्यान्वेषण पश्चात् ग्राह्य तथ्यहरूलाई अंगीकार गरिएको छ। ती सबै मौलिक, प्राथमिक र पुस्तकालयीय स्रोतहरूबाट प्राप्त तथ्यहरूका आधारमा प्रस्तुत रचनाको शीर्षकलाई न्याय गर्ने हेतुले यो रचना तयार पारिएको छ। समयसीमा र शीर्षकको मागबमोजिमको परिधिभित्र रहेर रचना तयार गर्दा सबै पक्षहरू समेट्न सकिएको छैन ।

\section{अध्ययनको महत्त्व}

आजको संसार भौतिक विकास र सांसारिक सुख, भोग-विलासबाट बढी प्रभावित छ, विश्व भूमण्डलीकरणमा यी सन्दर्भहरू पर्याय बनेर आएका छन्। यसले गर्दा आफूमात्रै शक्तिशाली बन्ने, समृद्ध बन्ने, भौतिक रूपमा निपूर्ण हुने होड चलेको छ। यो 'विजिगिषु' प्रवृत्तिले विश्वलाई संकटग्रस्त तुल्याउँदै लगेको छ। देश-देशाटनमा अनेकौँ अपराधिक गतिविधिहरू तेजरफ्तारमा अभिवृद्धि भइरहेका छन् । अमानुषिक, अशोभनीय र अन्याय-अत्याचारका घटनाहरू सिक्रीगत (Chain of events) रूपमा घटित भइरहेका छन्। 
यसले गर्दा विश्वमा हत्य, हिंसा, आतंक, बलात्कार, अपहरण, व्यभिचार लगायतका युद्ध फसादजन्य अमानवीय विषयले समाजलाई आक्रान्त तुल्याइरहेको छ। दिनानुदिन समसामयिक पक्षहरूको विकास प्रकृया अवरुद्ध हुँदैछ। विभेद र विषमताको भूँवरीले मानवीय मूल्य र मान्यतामा ह्रास ल्याउने र खलल उत्पन्न गर्ने गरिरहेको परिप्रेक्ष्यमा बुद्धदर्शनसँग सन्निहित कार्यकुशल कर्महरूले मात्र मानवीय जीवन पद्धतिलाई आरक्षित गरी त्यसलाई अक्षुण्ण राखन सक्छ (शाक्य र शेर्पा, २०७४ : २७, ३५, ७६, २०१, २ ९१)। बुद्धद्वारा प्रदत्त चार पवित्र आर्य सत्य, अष्टाड्गिक मार्ग, नैतिक आचरणका लोकधर्म, उत्तम-मंगल धर्म दशपारमिता लगायतका मानवीय व्यवहारिक प्रयोजनका अनेकानेक शील समर्पित प्रज्ञाजस्ता विशिष्ट सन्दर्भद्वारा प्रत्येक मानिसको अन्तरमनभित्र स्वपहिचान एवं स्वरक्षा गर्दे स्वावलम्बी बनाउन सकिने कुरालाई नकार्न सकिंदैन ।

सोच, बुद्धि-विवेक र मनलाई सुरक्षित तवरले राख्ने र चलायमान गराउने हाम्रो शरीर क्षणभंगुर छ। यो अनित्य पनि छ। नश्वर हुनाले अजर-अमर छैन। शास्वत-सत्य विषयमात्र अजर-अमर हुन्छन् अर्थात् मानवीय कृयाकलापबाट उत्पन्न परिणाम चाहीं अमर रहन्छन् । त्यसैले “म मेरो शरीरको मालिक हुँ”, "दु:ख-सुख दुबैको उपज पनि म आफैं हुँ" भनेर राम्रा सकारात्मक परिणाममुखी कदम चाल्न प्रत्येक मानिसलाई बुद्ध दर्शनमा अभिप्रेरणा तथा उत्प्रेरणा प्रदान गरिएको छ। जीवनलाई प्रभावोत्पादक, उपयोगी, उपलब्धिमुलक र गुणवता सावित गर्न उक्त दर्शनले अग्रदूतको भूमिका निर्वाह गर्दछ (मानन्धर, २०७६ : १४-१५) । अत: मानवीय जीवन पद्धतिलाई सार्थकतापूर्ण तवरले परिचय गर्न बुद्धदर्शनको महत्त्वपूर्ण योगदान हुनुका साथै यो जीवन पद्धतिको अनिवार्य पहलु हो । त्यसैगरी मानव जीवनको अपरिहार्य सूत्र पनि हो। यही वास्तविक, वस्तुनिष्ट सत्य र महत्त्वलाई उजागर गर्ने उद्देश्यबाट लक्षित भएर प्रस्तुत विषयको रचना तयार गरिएको हो ।

\section{विषय प्रवेश}

विश्वमानचित्रमा मौलिक बनावट, संरचना, पद्धति, प्रणालीहरू कायम रहेका आफ्नै राष्ट्रिय सीमा र शासकीय गुणहरू भएका थुप्रै देशहरू अस्तित्वमा छन्। कुनै देश राजतत्त्रात्मक प्रणालीमा छन् भने कतिपय देशहरू गणतन्त्रात्मक शासन प्रणालीमा आधारित छन्। सबैका फरक र मौलिक विशिष्टताहरू छन् । त्यहाँ निवास गर्ने र आजीविका चलाउने नागरिकहरूका पनि स्वपहिचानयुक्त समाज, धर्म, संस्कृति र सभ्यताहरू मौलिक किसमले हुर्किरहेका छन् (धाख्वा र श्रेष्ठ, २०४६ : १०)। कतिपय देशहरूले लोककल्याणकारी सरकार चयन गरेर जनप्रीय कदमहरू चाल्दै मुलुक र जनताको सर्वोपरी हितलाई उच्च प्राथमिकता प्रदान गरेर शासन संयन्त्र संचालन गरेका छन्। त्यहाँ विभेद, विषमता र अनेकतापूर्ण कटुता न्यून मात्रामा छ। कतिपय देशले प्रजातात्त्रिक मूल्य र मान्यतालाई सत्तासीनहरूको समृद्धिको भय्याङ्र मात्र बनाएका छन्। त्यहाँ अनेकता, वैमनस्यता र अवन्नतिले घर गरेको छ। विसंगतिको उरुङ-थुप्रोबाट अमृतको वर्षा हुने कुरै भएन । त्यस्ता देशहरूमा सरकारको असावधानी, 
अकर्मण्यता र अराजकताबाट समाजमा उत्पीडन व्याप्त भएको छ (गौतम, अन्तर्वार्ता)। सामाजिक अपराध, दुर्व्यवहार, दूराचार, व्यभिचारजस्ता अमानवीय कृयाकलापहरू दिनदिनै बढोत्तरीमा छन् (शाक्य, २०६४ : १४, ३०, ४४, १५७)। त्यहाँ सरकारी निकायको पहुँच पुगेकै छैन । पहुँच पुगे पनि दिनदु:खीको हितमा हुँदैन । जहाँ मानवीय मूल्य हराइरहेको छ। नागरिकहरूको शान्तिपूर्ण बाँच्न पाउने अधिकार कुण्ठित भएको छ। प्रजातन्त्रको मिरमिरे उज्यालोले आफ्नो घरको आँगन स्पर्श गर्न पाएकै छैन (धाख्वा, प्रवचन)। मानवीय जीवन अनेक किसिमका उत्पीडन र प्रताडनाले घेरिएको छ। विकासका पूर्वाधारहरूको रूपरेखा शुन्यप्रायः छन् । यस्तो अवस्थामा शान्तिपूर्ण आजीविकाको अवसर नहुँदा दैनिक जीवन नै कष्टकर रूपमा व्यतित भइरहेको छ, (गुरुमाँ, २०७४ : १३)। यी सबै अवगुणहरूले शान्ति र अमनचयन खल्बल्याईरहेको छ। यी र यस्ता गतिविधिहरू विश्वका प्राय: सबै देशमा व्याप्त छ। त्यहाँका जाति विशेष, वर्ग विशेष, समुदाय विशेष र धर्म विशेषलाई पनि यस्ता विसंगतिहरूले संत्रस्त तुल्याइरहेको छ। यस्तो अशोभनीय अवस्थाबाट त्राण पाउन “बुद्धदर्शन" का कल्याणकारी बहुआयामिक आयामहरू ग्रहण गर्न लायक बन्न र सर्वग्राह्य हुन वान्छनीय छ।

बुद्धदर्शनले धर्मको मात्र सूत्रपात गरेको होइन । यसले केवल अध्यात्मतर्फको चिन्तनलाई मात्र प्रतिविंवित गर्देन । बुद्धदर्शनले मानव भएर जन्मेपछि, मृत्युपर्यन्त गर्ने व्यवहारिक जीवन पद्धतिलाई पनि समेटेर नैतिक आचरण र सदाचारका कुराहरूमा कसरी अगाडि बढ्ने भनेर निर्देशित गरिदिएको छ (अमृतानन्द, २०४९ : २१)। सामाजिक प्राणी भएर व्यवहार कुशल कसरी हुने ? अकुशल र क्लेशयुक्त आशक्तिपूर्ण क्षण एवं कार्यबाट कसरी बच्चे ? सबै प्रसंगहरूलाई मानवोचित ढंगले अंगिकार गर्न सुभाइएको देखिन्छ। त्यतिमात्र नभएर लोकोत्तरमा अमर र अजर हुने पवित्र, सकारात्मक र गुणकारी मार्गहरू समेतको रेखांकन गरिएको पाइन्छ (शाक्य, २०६४ : २७)। विश्वको मौजुदा परिदृश्यको मापन गर्दा पनि बुद्धदर्शनलाई मानव जातिले ढिलो-छिटो अंगिकार नगरी नहुने परिवेश सिर्जना हुँदै गएको छ।

\section{मानवीय जीवन}

स्थूल शरीरको जन्म हुनु आफैंमा आश्चर्यजनक सन्दर्भ होइन । शुन्य मानषपटलभित्र कमिक रूपमा नैतिक र चारित्रिक गुणहरू प्रवेश गराई पंचशीलका सकारात्मक पक्षहरूबाट ओतप्रोत गराउनु नै स्थूल शरीररूपी रक्षा कवचभित्र मानवीय जीवनलाई विवेकशील तुल्याउने प्रमुख दायित्व हो । शील, समाधि र प्रज्ञाका माध्यमबाट मानव शरीरभित्र अनेकौं विशिष्ट गुणहरूले भरिपूर्ण बनाइसकेपछि शरीरले आन्तरिक र बाह्य अवयवहरूको गुणदोष पर्गेल्न सक्षम हुन्छ। शरीर नश्वर, अनित्य र क्षणभंगुर हुने हुनाले यसलाई अस्थिर नै मानिन्छ (शर्मा, अन्तर्वार्ता)। यद्यपि त्यही शरीरभित्र प्रवेश भएका बुद्धदर्शनका बहुआयामिक, बहुउपयोगी र बहुगुणी विशिष्टतम कल्याणकारी पक्षहरूले उक्त शरीरलाई आकृति, प्रकृति र स्वरूपमा परिचित गराउँछ् (मानन्धर, २०७६ : १४-१६)। मानिसको मन, हृदय अर्थात् समग्रमा अन्तरमन विशुद्ध, स्थीर र स्थायी हुन पुगदछ। "मानषपटललाई प्रज्ञा" का श्रुतमय प्रज्ञा, चिन्तनमय प्रज्ञा र भावनामय प्रज्ञाको प्रवेश गराइसकेपछि बुद्धि-विवेकले ठीक ढंगबाट शरीरलाई चलायमान गराउन सक्छ। त्यसैगरी पंचशीलका गुणहरूद्वारा सदाचारमुक्त नैतिक आचरण विकसित 
हुन पुगदछन् (बज्राचार्य, २००० : ७७)। पवित्र आर्य सत्य, अष्टाइ्रिक मार्ग, लोकधर्म, उत्तम-मंगल धर्म लगायतका चारित्रिक विशेषताहरूको अवलम्बन पश्चात् मानवजीवन विवेकशील प्राणीको रूपमा प्रख्यात हुन पुग्छ। यद्यपि ख्याति, प्रसिद्धि र लोकप्रियता प्राप्त गर्न बुद्धदर्शनका प्रभावशाली आचरणद्वारा अनुप्राणित हुनु आवश्यक पर्दछ।

बुद्ध दर्शनमा मानिसलाई सर्वोपरी स्थान प्रदान गरिएको छ। “आफ्नो मालिक, नाथ आफैं हो"। "आफ्नो समस्यामा अरुको शरण नपर, आफ़नै शरणमा जाऊ”। “आफ्नो बत्ती आफैं बन" भनेर मानिसलाई स्वत्वको रक्षा गर्दे यसले आफैँलाई स्वावलम्बी बनाउन मद्दत पुच्याउँछ (संघ, २०६५ : २५)। अर्थात् "मानिस स्वयम बुद्ध (ज्ञानी) बन र मानिस स्वयमले बोधिसत्व प्राप्त गर्न सक”। जसले गर्दा सबै प्राणीहरूबीच सहअस्तित्वबोधको भावना अक्षणण राख्दा राख्दै मानिसलाई प्रत्येक प्रहर आफ़ना वरिपरि र वाह्य जगतका समस्याहरूलाई आफैंभित्रबाट निदान-निवारण खोज्न प्रोत्साहित गरिएको छ। मानिसको सर्वोच्चता, गरिमा र प्रभावकारितालाई बुद्ध दर्शनले सर्वकालिक बनाएको दृष्टिगोचर हुन्छ।

\section{व्यवहारिक जीवन}

नेपाल बुद्धभूमि हो, पुण्यभूमि हो र तपोभूमि पनि हो (शाक्य, २०६४ : १३६)। यस्तो पावनभूमिमा जन्मन पाउनु र कर्मभूमिको रूपमा आफ्ना बैध गतिविधि संचालन गर्न पाउनु पनि गौरवको विषय हो। बुद्धले समेत नेपाल जस्तो देशमा बस्ने सौभाग्य पाउनुलाई उत्तम मंगल क्षण भनेर प्रवचनमा देशना गरेको पाइन्छ। मानविय गुणहरू प्रवर्द्धन गर्दे व्यवहारिक कृयाकलापहरू अगाडि बढाउनका लागि अनेकौं मांगलिक उपायहरूको समेत ज्ञान प्रवाहित गरिएको छ। व्यक्ति परिवारको हितकारी हुँदै समाज, राष्ट्र र विश्वकै कल्याणमा आफूलाई समाहित गर्न सक्षम हुन्छ। समाजका सबै वर्ग, वर्ण, जात, धर्म, लिङ्रप्रति समताभाव राख्न सक्ने स्वतन्त्र, न्यायप्रिय, मैत्री र करुणामयी व्यक्ति समाजको निमित्त सबैभन्दा व्यवहारिक र कार्यकुशल मानिन्छ (शाक्य र शेर्पा, २०७४ : ६७, ९७, २१९)। आफूभन्दा बढी परमार्थलाई कल्याणको उच्चबिन्दु ठान्ने, समताभाव राखने, सदभावनायुक्त प्रवृत्ति प्रदर्शन गर्ने, सहयोगात्मक प्रवृत्ति भएको व्यक्ति अधिक व्यवहारिक हुने न्यायसंगत तर्कहरू बुद्धदर्शनमा सविस्तार वर्णन गरिएका छन् । मानवजीवन सधैं ठूलो, लामो, सजिलो, पिच सडकमा हिंड्न सक्ने अवस्थामा हुँदैन (मानन्धर, २०७६ : १४-१६) सरल रेखामा पनि अग्रसर हुन सकिँैन । कठिनाई, विघ्नवाधा, अड्चन व्यवधानका बीचबाट आफूलाई सफलतापूर्वक हिँडाउनु पछ। सुख र दु:खका दुवै वातावरणमा अविचलित भएर मर्यादापूर्ण किसमले यावत व्यवहारिक उल्कनबाट माथि उठ्नु पर्दछ (भण्डारी, प्रवचन)। मानिसलाई अप्ठयारो र संकटकै बेला चिन्न पाइन्छ। दु:खमा दु:खै थपिदिने व्यक्ति हितकारी हुनै सक्दैन । दु:ख र सुखमा समभाव वा समताभाव राख्ने व्यक्ति नै व्यवहार कुशल र असल हितोपकारी ठहछ।

मानव जीवनको व्यवहारिक पक्ष निकै जटिल, सम्वेदनशील र चुनौतिपूर्ण मानिन्छ। व्यवहार उच्निच् भयो भने कमाएको प्रतिष्ठा क्षणभरमै समूल नष्ट हुन्छ। तर्कसंगत र न्यायसंगत काम गर्न सकिएन भने पनि आलोचनाको तारो बन्नु पई। विवेक नपुय्याई कुनै कार्यसिद्धि गरियो भने त्यसले सबैको हित गर्दैन (शाक्य, २०६४ : ५३९०)। कोही रुष्ट र असन्तुष्ट भैदिन्छ। यस्तो स्थितिमा समाजमा आर्जन गरेको लोकप्रियता एकैछिनमा स्खलित 
हुन पुग्छ। वडा सावधानी र सचेतनाका साथ व्यवहारिक जीवनका पाइलाहरू चाल्नु पई (लि., २०१० : पू६, ६७, ७१)। बुद्धदर्शनमा मानवीय व्यवहारिक जीवन पद्धतिलाई सुखमय तुल्याएर सुमधुर सम्बन्धका साथ आफूलाई स्थापित गरी कदरयोग्य बनाउन थुप्रै किसिमका शिक्षाहरू प्रदान गरिएको पाइन्छ।

\section{नैतिक आचरण}

मानवीय जीवन अनमोल हुँदाहुँदै पनि यो नितान्त क्षणिक छ। जन्मपछि, निर्वाण प्राप्त गर्ने कुरा सँगसँगै छायाँजस्तै अन्योन्यास्रित भएर पच्छूयाइरहन्छ। काँढाहरूको बीचमा फूलेको फूलजस्तो सुगन्धित, सुन्दर र नयनप्रिय बनाउन सकिएन भने यसको सार्थकता र जन्मिनुको औचित्य पुष्टि हुँदैन । बुद्धले मानवीय जीवनलाई सफलताको सिढी कसरी चढ़न सकिन्छ भन्ने सन्दर्भमा थुप्रै सदाचारयुक्त धर्मदेशना गर्नुभएको छ। शील, समाधि र प्रज्ञाका अनेक चरणसंगै नैतिक चारित्रिक गुणहरूलाई निखार्ने पंचशीलको अवधारणा सिद्धान्ततः प्रतिपादन गर्नुभएको हो (अमृतानन्द, १९९९ : ४७७)। हिंसा नगर्ने अर्थात अहिंसात्रती हुने र त्यसका लागि नियमहरूको अक्षरश: पालना गर्ने अठोट गर्नसक्नु पच्यो। अरुको सम्पत्ति चोरी नगर्ने अर्थात् अरुको धनसम्पति हत्याउने, ठगी गर्ने र आफ्नो कब्जामा पार्ने कार्य कदापि गर्नु भएन। यस किसिमको आशक्तिले मेहनत र परिश्रम नगरी जीवन निर्वाह गर्ने प्रवृत्तिको विकास हुन्छ (लामा, प्रवचन)। जुन सदाचारभित्र पर्दैन । त्यसैगरी व्यभिचारी नबन्नका लागि पन्चशीलको तेस्रो शिक्षापदमा देशना गरिएको छ। व्यभिचार, मिथ्याचार, दूराचार जस्ता निकृष्टतम कार्य गर्नु हुँदैन र यसलाई जीवनभर परिपालना गर्नुपर्दछ भनेर मानिसलाई सदाचारमा कटिबद्ध भएर यसका नियमहरूको परिपालनामा उत्प्रेरणा जगाइएको पाइन्छ। त्यसैगरी कूठो कुरा नगर्नु, मिथ्या वाणी स्फूरण नगर्नु भनेर सदाचारको चौथो शिक्षापदले मानिसलाई सत्यवचनतर्फ आकर्षित गरेको छ। मानिसको बोलीबचन, शब्दसंगति र प्रयुक्त वाक्य विन्याशले शिष्टाचार भल्किन्छ (आचार्य, १९५४ : ९१)। शालिनतापूर्वक अभिव्यक्त वाणी कर्णप्रिय मात्र नभएर सानिध्यतापूर्ण सुमधुर हुन्छ (स्वामीजी, अन्तर्वार्ता)। त्यसबाट शिष्टता प्रस्फुटित हुन्छ, विनम्रता प्रदर्शित हुन्छ र सत्यवचनबाट न्यायप्रियता समेत प्रकट हुन्छ। यो पनि शील प्रयुक्त सदाचार हो र नैतिक आचरणलाई यसले अरु निपूर्णता प्रदान गर्दछ। सुरापान नगर्न प्रोत्साहन दिने सदाचारको पाँचौँ शिक्षापद हो (अम्बेडकर, १९५७ : ११३)। मादक पदार्थ, रक्सी, जाँड, भाड्ग, धतुरो, ड्रगसजस्ता कूलतमा फसाउने र अनमोल मानवीय जीवनलाई शारीरिक र मानसिक रूपमै समाप्त पार्ने काम कसैले पनि गर्नु हुँदैन भनेर बुद्धले आफ्नो औपदेशिक शिक्षामा सविस्तार प्रवचन दिनुभएको छ (अम्बेडकर, १९५७ : ९७)। सुरापानको कूलत ज्यादै खतरनाक हुन्छ। यसले समाजभित्र अनेकौं किसिमका विकृतिहरू भित्र्याउँछ। आर्थिक, सामाजिक एवं नैतिक मूल्य र मान्यताहरूलाई विनास गई (क्याक्ल, २०१६ : १०३)। परिवार, इष्टमित्र, कुलकुटुम्बभित्र कगडा, वैरत्व र शत्रुता बढाउँछ र समाजलाई नै यसले आक्रान्त तुल्याउँछ।

यसरी सदाचारका नियम र पद्धतिहरूलाई परिपालना गर्ने व्यक्ति शीलवान, इमान्दार, निर्भिक, निर्दोष, आत्मविश्वासी, आत्मसम्मानित र अनुशासित हुने हुनाले समाजमा उसलाई पुज्यनीय व्यक्तित्वको रूपमा ग्रहण 
गरिएको हुन्छ (प्रधान, १९६६ : ३७)। यसले मानिसलाई मर्यादित, कदरयोग्य र सम्मानपूर्ण दृष्टिले हेर्न मद्दत पुच्याउँछ। नैतिक आचरणले मानवीय जीवन पद्धतिलाई सम्मानित स्थान प्रदान गर्दछ।

\section{उपसंहार}

बुद्ध धर्म मानवोपयोगी र व्यवहारगत चिन्तनमा आधारित दर्शन हो । यसको अध्ययन, अनुशीलन प्रकृयाले मानवीय अन्तरमनभित्र मध्यस्थ बिन्दुबाट जीवनका आरोह-अवरोह निवारणार्थ प्रयत्न गर्न आत्मिक निर्णय शक्ति र ऊर्जा उपलब्ध गराइन्छ। कोध, अशान्ति, नैराश्यता, लोभ, लालच, ईष्य्या, डाहा, घमण्ड, अहंकार, मोह, माया जस्ता सांसारिक समवेगहरूलाई कुनै अनुराग-वैराग नराखी तटस्थतायुक्त तौरतरिकाबाट निष्कर्ष निकाल्न धैर्यता प्रदान गर्दछ। आफ्नै दु:खमा चरम निराशाको पीडा महशुस नगरी त्यसलाई सहज रूपमा सहर्ष स्वीकार गर्न स्वतन्त्र हुने र अरुको सुखमा पनि आफू सुखी भएको अनुभूत गर्न सक्ने मध्येस्थतावादी प्रवृत्तिबाट उभ्याउन सक्नु उक्त दर्शनको विशिष्ट पक्ष हो। बुद्ध दर्शनको प्रभावले समाजभित्रका समसामयिक पक्षहरूलाई समेत सक्रिय तुल्याउँछ। राजनैतिक पक्षभित्र देखापर्ने “किम कर्तव्य विमूढ” को अकार्य कुशल प्रवृत्तिलाई उजागर गर्ने र त्यसलाई जनकल्याणतर्फ अग्रसर हुने अभिप्रेरणा जागरित गराउँछ। सामाजिक क्षेत्रमा भएका विसंगतिपूर्ण विषमताहरूलाई निराकरण गर्न र नैतिक आचरणबाट समाजलाई गतिशील तुल्याउन प्रोत्साहित गर्दछ। आर्थिक अवस्थामा देखिएका अन्तरविरोध र असमान परिस्थितिलाई इमान्दार प्रयत्नद्वारा उन्नतिको यात्रा तय गर्न उत्प्रेरणा जगाउँछ। धर्म-संस्कृतिको क्षेत्रमा देखिएका अवैज्ञानिक लक्षणहरूलाई समयानुकूल सुधार र परिवर्तन गर्न गराउन यसले उत्साहित तुल्याउँछ। समग्रमा व्यक्तिलाई परिवारसँग, परिवारलाई समाजसँग, समाजलाई राष्ट्रसंग र राष्ट्रलाई ब्रम्हाण्डसम्म आवद्ध बनाएर जीवन निर्वाह गर्दा कहिल्यै बद्नाम र आलोचनाको तारो नबनी शान्तमय वातावरणमा जीवन व्यतित गर्न बुद्ध दर्शनले नै मार्ग प्रशस्त गर्दछ। बुद्ध धर्म तथा दर्शनमा सबैखाले दूरावस्थाबाट बचाउन सकिने साधना, तपश्या, विपश्यना, मन्त्रोच्चारण विधि र प्रकृयाहरु सुनिश्चित गरिएका छन् । अतिवृष्टि, अनावृष्टिबाट बच्न, नदी-पोखरीको पानीबाट जीवन बचाउन, कृत्रिम र प्राकृतिक प्रकोपबाट बचाउन, पानी पार्न, नदीलाई अर्के दिशा फर्काउन, सपनाको दोष हटाउन, क्लेशीपनलाई अक्लेशी तुल्याउन, ऋोधलाई करुणामा बदल्न सम्मकै अनेक कार्यविधिहरु प्रयुक्त गर्न सकिन्छ। त्यसैले बुद्धका शिक्षा, उपदेश, देशना, मानवोचित छन् । अत्यन्त उपयोगी पनि छन्। मानवीय जीवन पद्धतिमा बुद्धदर्शनको आवश्यकता, औचित्यता नि:सन्देह अनिवार्य जस्तै भएको छ। जीवनको सार्थकता समेत यसैमा अन्तरनिहित हुन पुगेको छ। 


\section{सन्दर्भसूची}

\section{प्राथमिक स्रोत}

गौतम, बद्रिनारायणसंग २०७७.५.२ गते लिएको अन्तर्वार्ता । डा. गौतम नेपाल तथा एशियाली अनुसन्धान केन्द्रका अनुसन्धानकर्ता, इतिहासकार, लेखक एवं नेपालको प्रजातात्त्रिक आन्दोलनका विशेषज्ञ अध्येता हुनुहुन्छ।

धाख्वा, सविताद्वारा प्रस्तुत प्रवचनबाट प्राप्त सूचनाका आधारमा । युटुव नेटवर्क ।

भण्डारी, कमलसँग युटुबमा अपलोड भएका विशेष प्रवचनहरू। भण्डारीज्यू नेपाल बौद्ध महासंघका तत्कालिन महासचिव हुनुहुन्छ।

लामा, दलाईको धर्मदेशना-चित्तशोधन पार्ने विधि सम्बन्धी प्रवचन, अनुवादक, शील, बागिन्द्रसेन रिम्पोछे/युटुवमा

प्रस्तुत प्रवचन ।

शर्मा, विमलकुमारसँग २०७७.७.३० गते लिएको टेलिफोन सम्पर्कद्वारा प्राप्त सूचनाबाट। प्रा. शर्मा अवकाशप्राप्त

प्राध्यापक, अनुसन्धानकर्ता, सामाजिक अभियन्ता, एवं लेखक हुनुहुन्छ। उहाँले लुम्बिनी विकास कोषको पूर्व सदस्यसचिव भएर जिम्मेवारी निर्वाह गरिसक्नु भएको छ।

स्वामीजी, हरिदास, युटुबमा प्रस्तुत बुद्ध सम्बन्धी सारगर्भित विचार प्रस्तुतीकरणबाट प्राप्त सुचनाका आधारमा ।

स्वामीजी आर्ट अफ लाइफका प्रभावशाली अभियन्ता हुन् ।

\section{पुस्तकालयीय स्रोत}

अमृतानन्द, भिक्षु (१९९९), संक्षिप्त बुद्ध जीवनी, लुम्बिनी : अन्तर्राष्ट्रिय बौद्ध समाज ।

..., (२०६०), गृही विनय परियति, काठमाडौँ : ने. बौ.प.संघ ।

अम्बेडकर (क), भीमरावजी (१९५७), भगवान् बुद्ध और उनका धम्म, मुम्बई : सिद्धार्थ महाविद्यालय

प्रकाशन ।

(१९५७), दि बुद्ध एण्ड हिज धम्म, बम्बई : सिद्धार्थ कलेज पब्लिसर्स ।

आचार्य, चतुरसेन शास्त्री (१९४०), बुद्ध और बौद्ध धर्म, देल्ली : हिन्दी साहित्य मण्डल ।

आचार्य, नरेन्द्रदेव (१९५४), बौद्ध धर्म दर्शन, दिल्ली : मोतिलाल वनारसीदास पब्लिसर्स प्रा.लि. । क्याकल, बुक्को ड्याण्डो (२०१६), भगवान बुद्धका उपदेश, टोकियो जापान : कोसाइको के.लि.। गुरुमाँ, अनोजा (२०७४), मंगल उपदेश, कीर्तिपुर : लेखक स्वयम् ।

धाख्वा, सविता र श्रेष्ठ शान्तालक्ष्मी (२०४६), नारीपुरुष समविकास निर्देशिका, ललितपुर : ग्रामिण विकास परियोजना ।

प्रधान, भुवनलाल (१९५५), नेपाल बौद्ध दर्शन, काठमाडौँ : नेपाल प्रज्ञा प्रतिष्ठान । बज्राचार्य, दुण्डबहादुर (२०००), दीधनिकाय, प्रथम भाग, ललितपुर : वीर पूर्ण पुस्तक संग्रहालय । भिक्षु संघरक्षित (२०६५), बुद्धकालीन दशअग्रणी नारीहरू, ललितपुर : सत्यसन्देश प्रचारक प्रकाशन । 
मानन्धर, त्रिरत्न (सं.), (२०७६), बुद्ध शिक्षाका आयामहरू, काठमाडौं : केशरमान ताम्राकार र अरुहरू । लि. टि. वाई. (२००६), लाइफ अफ ब्लेसिद्रस, टोकियो जापान : केप मिडिया इन्टरनेशनल।

(२०१०) द पाथ टु ह्याभेन एण्ड वियोण्ड टु निव्वाना, टोकियो जापान : केप मिडिया इन्टरनेशनल। (२०१०), एनिवन क्यान गो ह्याभेन जस्ट वि गुड, टोकियो जापान : केप मिडिया इन्टरनेशनल । शाक्य, दोलेन्द्ररत्न (२०६४) समता धर्मको पालना, ललितपुर : महेन्द्ररत्न शाक्य, विरेन्द्ररत्न शाक्य र संगीता शाक्य ।

(अनु.), (२०६४), बुद्धकालीन बाह्न सन्नारीहरू, ललितपुर : मोक्षदेबी राजकर्णीकार ।

शाक्य, मिलन र शेर्पा टीका, (अनु. ), (२०७४), प्रियलामा जोपा-समस्याहरूलाई सुखमा बदल्ने कान्तिकारी समाधानहरू, काठमाडौं : नेपाल बौद्ध महायान केन्द्र, गोन्पा । सान्तिना, पिटरडेला (१९९७), द ट्रि अफ इन्लाइटमैन्ट, ताइवान : सिबिको धर्म स्टडी फाउन्डेसन । 